\title{
防波堤のチャート式耐震診断手法に関する 基礎的研究
}

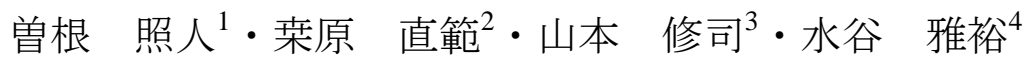 \\ 近藤 武司 ${ }^{5}$. 森本 徹 6 . 井合 進 $^{7} \cdot$ 一井 康二 8 \\ 1正会員 株式会社ニュージェック 港湾・海岸グループ 沿岸防災チーム \\ （干531-0074大阪市北区本庄東2丁目3番20号） E-mail:sonekt@newjec.co.jp \\ 2正会員 株式会社ニュージェック 港湾・海岸グループ 沿岸防災チーム \\ （干531-0074大阪市北区本庄東2丁目3番20号）Ｅ-mail:kuwabarann@newjec.co.jp \\ 3正会員 財団法人 沿岸技術研究センター（テ102-0092 東京都千代田区隼町3-16） \\ E-mail:s-yamamot@cdit.or.jp \\ 4国土交通省 近畿地方整備局 神戸港湾空港技術調查事務所（ \\ E-mail: mizutani-m2sa@pa.kkr.mlit.go.jp \\ 5 国土交通省 近畿地方整備局 和歌山港湾事務所（干640-8404 和歌山市湊薬種畑の坪1334） \\ E-mail:kondou-t86s4@pa.kkr.mlit.go.jp \\ 6国土交通省 近畿地方整備局 神戸港湾空港技術調査事務所（广651-0082 神戸市中央区小野浜町7-30） \\ E-mail:morimoto-t86s3@pa.kkr.mlit.go.jp \\ 7正会員 京都大学防災研究所（干611-0011 京都府宇治市五ヶ庄） \\ E-mail:iai.susumu.6x@kyoto-u.ac.jp \\ 8正会員＼cjkstart広島大学大学院（干739-8527東広島市鏡山1-4-1） \\ E-mail:ichiikoji@hiroshima-u.ac.jp
}

防波堤は高潮や津波から背後地の資産や生命を護るための重要な施設である。将来，来襲するであろう 津波や高潮に対する防護機能を確保するために実施する，設計や防災計画を検討する上では，地震時の防 波堤の沈下量を適切に把握することが非常に重要である。沈下量を精度よく把握する手法としては，有限 要素法による2次元地震応答解析(以下，2次元解析)が挙げられるが，この手法は計算負荷が大きく，多く の断面の照査を行う上では実務上の観点からは現実的では無い。そこで，本研究では，これに替わるもの として堤防タイプの沿岸構造物のチャート式耐震診診断システムに, 防波堤重量に関する補正 係数，及び堤体の物性に関する補正係数を加えることにより，重力式防波堤のチャート式耐震 診断手法を提案し，被災事例等の3事例について概ね再現できることを確認した。

Key Words : breakwater, earthquake response analysis, settlement after the earthquake, evaluation of earthquake resistance, liquefaction

\section{1. はじめに}

2011年3月に発生した東北地方太平洋沖地震以外にも， 全国の沿岸域で巨大地震の発生と，それに伴う津波の来 襲が懸念されている. 東北地方太平洋沖地震では, 巨大 津波の来襲により，防波堤が甚大な被害を受け，津波に 対して粘り強い構造を構築する必要性が浮き彫りとなっ た. 兵庫県南部地震では，神戸第7防波堤が基礎地盤の 液状化に伴い，約3m程度の沈下が確認されているなど 粘り強い構造を構築するためには, 津波来襲前に地震外 力により生じる防波堤の沈下量を適切に把握した上で,
対津波検討を実施することが重要である．本来，施設の 沈下量を適切に把握寸るには, 高度な解析(FEM等)を実 施する必要があるが，費用・時間等の問題から，簡易に 耐震診断照査ができるシステムの構築が必要である．地 震時の施設の変形量を簡易的に推定できる沿岸構造物の チャート式耐震診断システムは，今までのところ，海岸 保全施設を対象に直立型(重力式), 傾斜型(護岸タイプ), 傾斜型(堤防タイプ)が提示されているが，防波堤につい ては提示されていないのが現状である2)。そこで，本研 究では, 堤防タイプと防波堤の地震時の沈下のメカニズ ムは同じと考え，堤防タイプの沿岸構造物のチャート式 
而震診断システムを拡張し，重力式防波堤のチャート式 而震診断手法の提案を行ったものである.

\section{2. 沿岸構造物のチャート式耐震診断システム 【堤防タイプ】の概要}

東島ら゙は，堤防タイプについて図-1に示寸通り，堤 体地盤の天端幅，勾配，堤体高，水深，基礎地盤(等価 $\mathrm{N}$ 值, 液状化層厚), 及び地震動の速度のPSI值を用いて, それぞれの補正係数を定義し，基準沈下量 $\{1.5 \mathrm{~m}$ (標準夕 イプの沈下量)\}に対する補正後の沈下量を算出すること により種々の条件に対応した沈下量を算出寸るシステム を構築している(式(1)). なお, 標準タイプは後述する表1のcaseAである.

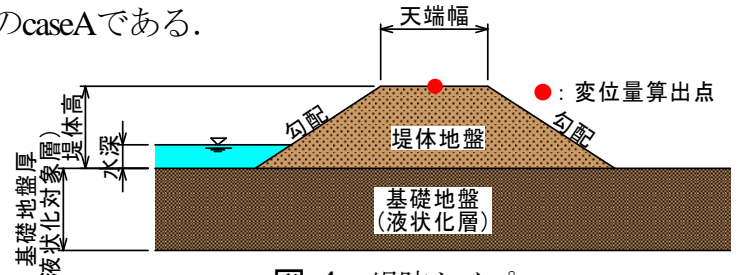

図-1 堤防タイプ

$$
S=b_{1} b_{2} b_{3} b_{4} b_{5} b_{6} b_{7} S_{r}
$$

ここに，bは補正係数を表し，それぞれ $b_{1}$ は天端幅， $b_{2}$ は堤防高， $b_{3}$ は勾配， $b_{4}$ は基礎地盤厚， $b_{5}$ は水深， $b_{6}$ は基 礎地盤の等価N值， $b_{7}$ は地震動の速度のPSI值に対する值 であり， $S_{\mathrm{r}}$ は基準沈下量(1.5m)，Sは推定する沈下量(m)で


で定義され，港湾構造物の変形量との相関が高く，地震 動を強さを表寸指標のつつである.

$$
\text { PSI }=\sqrt{\int_{-\infty}^{+\infty} v^{2}(t) d t}
$$

ここに, v(t)は速度 $(\mathrm{cm} / \mathrm{s})$ である.

\section{3. 検討概要}

堤防タイプ，防波堤とも地震時の沈下は，堤体あるい は，マウンド下の液状化の発生などに伴う地盤の剛性低 下による側方流動による影響が大部分であり，変形メカ ニズムは概ね同様であると考えた，そこで，東島ら ${ }^{2} の$ 既往検討により構築された, 堤防タイプの沿岸構造物の チャート式耐震診断システムを基に，堤防天端に防波堤 を想定した構造物を設置したモデルを構築し，堤防モデ ルから重力式防波堤モデルへの拡張を行った.

具体的には，図-2に示寸通り，防波堤を剛はり，質 点モデルに置き換えたモデルを構築した．本モデルを用 い，表-1に示寸 $\mathrm{A} \sim \mathrm{f} の 19$ 断面に対し，防波堤形状，重量 が与える影響を確認するため，防波堤幅W(2.0m)を固定
值として，防波堤高Hを2.0m(H/W=1.0), $1.8 \mathrm{~m}(\mathrm{H} / \mathrm{W}=0.9)$, $1.4 \mathrm{~m}(\mathrm{H} / \mathrm{W}=0.7)$ と変化させた3ケースについて検討を行っ た。なお，防波堤幅は，堤防天端幅が最も狭いcase aか ら設定している．また，上記3ケース(防波堤の形状のみ を変化)では，重量の影響を評価することが困難なため， ケーソン防波堤の単位体積重量 $\gamma=20\left(\mathrm{kN} / \mathrm{m}^{3}\right), \gamma=25\left(\mathrm{kN} / \mathrm{m}^{3}\right)$, $\gamma=30\left(\mathrm{kN} / \mathrm{m}^{3}\right), \gamma=40\left(\mathrm{kN} / \mathrm{m}^{3}\right)$ と変化させたケースについても 検討を行った. したがって, 検討断面数は, 堤防モデル のcaseA casefの19断面，防波堤形状3断面，単位体積重 量4ケースの228断面である.ただし，防波堤重量の検討 は, 水深十数メートルの防波堤断面までを想定できるよ うに, 前述したケーソン防波堤の単位体積重量に加え, マウンド形状が異なるcaseA, caseB, caseC, caseF, caseG, case a, case b, case cの断面 $\mathrm{H} / \mathrm{W}=1.0$ の防波堤形状のケー スを対象に, $\gamma=60\left(\mathrm{kN} / \mathrm{m}^{3}\right), \gamma=80\left(\mathrm{kN} / \mathrm{m}^{3}\right), \gamma=100\left(\mathrm{kN} / \mathrm{m}^{3}\right)$, $\gamma=130\left(\mathrm{kN} / \mathrm{m}^{3}\right)$ のケースを追加した. 断面 $\mathrm{H} / \mathrm{W}=1.0$ の防波堤 形状における各 $\gamma$ に対応するマウンド上面での単位面積 当たりの防波堤重量を表-2に示寸．これらの検討ケー スを対象に, 2次元解析を実施し, チャート式耐震診断 手法に必要な基準変形量に乗ずる補正係数を算出するこ とにより，防波堤のチャート式耐震診断手法を提案した。 その後, 提案したチャート式而震診断手法を用いて, 被 災断面や実験結果との比較を行うことにより，本手法の 精度の確認を行った. 2次元解析は解析コードFLIP)を用 いた，地盤は等価N值を10, 細粒分含有率 $F_{\mathrm{C}}$ ぜ゙ロとし た. 地盤の基本物性，及び夜状化パラメータは，FLIPに おいて標淮的な方法りに従って設定した。 また，対象と した地震動は, 最大加速度を150Gal(速度の PSI 値 $=45 \mathrm{~cm} / \mathrm{s}^{12}$ ), 300Gal (速度のPSI值 $=90 \mathrm{~cm} / \mathrm{s}^{12}$ ), 600Gal(速度の $\mathrm{PSI}$ 值 $=180 \mathrm{~cm} / \mathrm{s}^{12}$ ) に振幅調整した東南海・南海地震を対象 とした海南波を用いた(図-3参照).

補正係数を検討するケースは, 堤防タイプと同様(天 端幅・のり勾配・マウンド高・基礎地盤の液状化層厚の 影響検討)とするが，本研究では，防波堤重量の影響， 及び通常，マウンドには捨石材が用いられるため，堤体 $\left(\mathrm{N}_{65}=10\right)$ と捨石材との補正係数に関する検討を追加した. なお，速度のPSI值に関する補正係数と基礎地盤の等価 N值に関する補正係数は，堤防タイプの值を用いた。

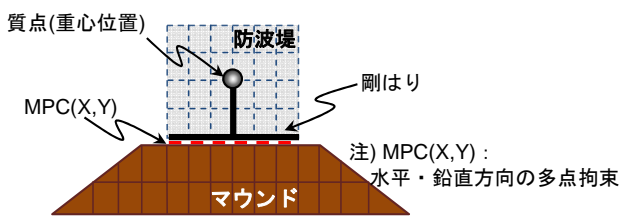

(1) 防波堤モデル

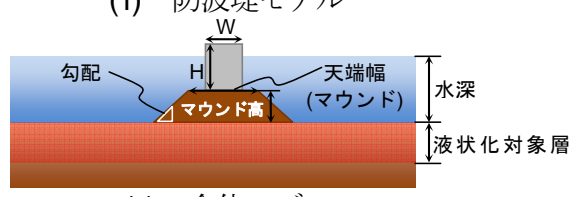

(2) 全体モデル

図-2 モデルイメージ 
表-1 検討断面ケース

\begin{tabular}{|c|c|c|c|c|c|c|c|c|c|}
\hline csae & $\begin{array}{c}\text { 天端幅 } \\
(\mathrm{m})\end{array}$ & $\begin{array}{l}\text { 勾配 } \\
1: 00\end{array}$ & $\begin{array}{c}\text { マウンド } \\
\text { 高 (m) }\end{array}$ & $\begin{array}{l}\text { 液状化対 } \\
\text { 象層 }(\mathrm{m})\end{array}$ & csae & $\begin{array}{c}\text { 天端幅 } \\
(\mathrm{m})\end{array}$ & $\begin{array}{c}\text { 勾配 } \\
1: 00\end{array}$ & $\begin{array}{c}\text { マウンド } \\
\text { 高 }(\mathrm{m})\end{array}$ & $\begin{array}{l}\text { 液状化対 } \\
\text { 象層 (m) }\end{array}$ \\
\hline $\mathrm{A}$ & 4.50 & \multirow{3}{*}{1.50} & \multirow{5}{*}{3.50} & \multirow{7}{*}{3.50} & $\mathrm{~K}$ & \multirow{3}{*}{4.50} & \multirow{9}{*}{1.50} & \multirow{5}{*}{3.50} & 5.25 \\
\hline B & 3.00 & & & & $\mathrm{~L}$ & & & & 7.00 \\
\hline C & 6.00 & & & & $\mathrm{M}$ & & & & 2.00 \\
\hline $\mathrm{D}$ & \multirow{7}{*}{4.50} & 1.25 & & & $\mathrm{a}$ & 2.00 & & & \\
\hline E & & 3.00 & & & $\mathrm{~b}$ & 8.00 & & & 3.50 \\
\hline $\mathrm{F}$ & & \multirow{5}{*}{1.50} & 3.00 & & c & \multirow{4}{*}{4.50} & & 7.00 & \\
\hline G & & & 5.00 & & d & & & \multirow{3}{*}{3.50} & 10.00 \\
\hline $\mathrm{H}$ & & & \multirow{3}{*}{3.50} & 2.00 & e & & & & 15.00 \\
\hline I & & & & 3.50 & $\mathrm{f}$ & & & & 20.00 \\
\hline $\mathrm{J}$ & & & & 0.00 & & & & & \\
\hline
\end{tabular}

表-2 防波堤重量

\begin{tabular}{|c|c|c|c|c|c|c|c|c|}
\hline & \multicolumn{7}{|c|}{ 解析モデルの $\gamma\left(\mathrm{kN} / \mathrm{m}^{3}\right)$} \\
\cline { 2 - 9 } & 20 & 25 & 30 & 40 & 60 & 80 & 100 & 130 \\
\hline $\begin{array}{c}\text { 単位面積当たり } \\
\text { の防波堤重量 }\left(\mathrm{kN} / \mathrm{m}^{2}\right)\end{array}$ & 44.1 & 53.9 & 63.7 & 83.3 & 122.5 & 161.7 & 200.9 & 264.6 \\
\hline
\end{tabular}
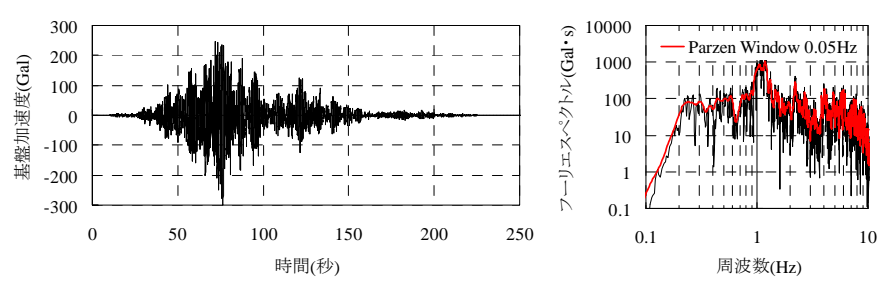

図-3 入力地震動

\section{4. 補正係数の検討}

補正係数の検討を行った，なお，堤防タイプと共通項 目である $b_{1} \sim b_{7}$ については，検討手法が同様であるため， 既報2)，及び利用者マニュアルの参照頂くこととし，検 討により得られた補正係数の式のみを示寸. 新たに追加 検討した防波堤重量による影響, 及び堤体と捨石材の違 いによる影響については詳細を示す。

\section{(1) 補正係数 $\left(b_{1} \sim b_{7}\right)$}

$b_{1} \sim b_{7}$ の補正係数の式を示寸. <マウンド天端幅に関する補正係数 $b_{1} \geq$

検討の結果，堤防タイプと同じ補正係数とすることと した．なお，本研究では，傾斜型(堤防タイプ)を基に検

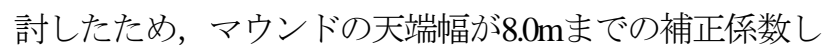
か検討していない．ただし，天端幅8.0mでは標準タイプ (天端幅 $4.5 \mathrm{~m}$ )に対する補正係数は $0.8 て ゙$ 収斂していると判 断できたため(図- 4参照), チャート式耐震診断手法は, 天端幅 $8.0 \mathrm{~m}$ 以上の施設についても補正係数 0.8 用いて診 断することとした.

$$
\left\{\begin{array}{lr}
y=\frac{1}{1.568} \cdot 3.7838 \exp (-0.1958) & (x \leqq 4.5) \\
y=-\frac{2}{35} x+\frac{44}{35} & (4.5<x \leqq 8) \\
y=0.8 & (x>8)
\end{array}\right.
$$

ここに，yは補正係数，xはマウンド天端幅(m)である.

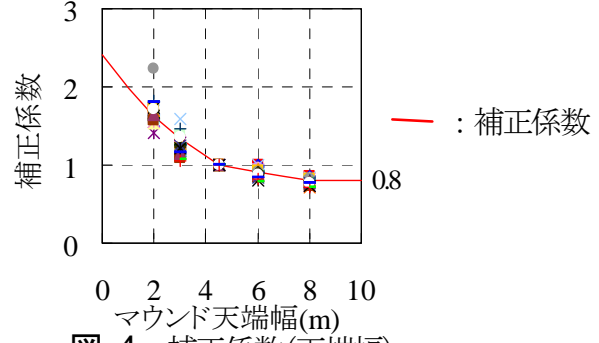

図-4 補正係数(天端幅)

<マウンド高に関する補正係数 $b_{2} \geq$

$$
\left\{\begin{array}{lrl}
y=\frac{1}{3.5} x & (x<3.5) \\
y=\frac{1}{3} x-\frac{1}{6} & (3.5 \leqq x<5) \\
y=1.5 & (5 \leqq x)
\end{array}\right.
$$

ここに，yは補正係数，xはマウンド高(m)である。た だし，適用範囲は， $(1.5 \leqq \mathrm{x} \leqq 7)$ とする.

$\leq$ のり勾配に関する補正係数 $b_{3} \geq$

$$
\left\{\begin{array}{cc}
y=-1.25 x+2.88 & (x<1.5) \\
y=-0.30 x+1.46 & (1.5 \leqq x \leqq 3)
\end{array}\right.
$$

ここに，y は補正係数， $x$ はのり勾配である.ただし， 適用範囲は， $(1.25 \leqq x \leqq 3.0)$ とする.

<基礎地盤厚に関する補正係数 $b_{4} \geq$

補正係数の上限值は，式(6)により設定する。また， 基礎地盤の液状化層厚がゼロメートルから式(7)に示す 補正係数の折れ点位置までは，原点を通り，折れ点位置 で補正係数の上限值となる線形の関係とする.

○補正係数の上限值

$$
\left\{\begin{array}{lr}
y=2 & (0 \leqq x<45) \\
y=-\frac{1}{45} x+3 & (45 \leqq x<90) \\
y=1 & (x \geqq 90)
\end{array}\right.
$$

○補正係数の折れ点位置

$$
\mathrm{z}=3.5 y
$$

ここに，yは補正係数， $x$ は速度の PSI 值 $\left(\mathrm{cm} / \mathrm{s}^{1 / 2}\right)$, $\mathrm{z}$ は基礎地盤の液状化層厚(m)である。ただし，適用 範囲は， $(\mathrm{z} \leqq 20)$ とする.

$\leq$ 水深に関する補正係数 $b_{5} \geq$

$$
\begin{aligned}
y & =1.0 \\
& \text { ここに, } y \text { は補正係数である. }
\end{aligned}
$$

<基礎地盤の N值に関する補正係数 $b_{6} \geq$

○速度のPSI值が $45\left(\mathrm{~cm} / \mathrm{s}^{1 / 2}\right)$ の場合

$$
\left\{\begin{array}{lr}
y=-0.212 x+4.182 & (0 \leqq x<15) \\
y=111.720 e^{-0.314 x} & (x \geqq 15)
\end{array}\right.
$$

○速度のPSI值が90( $\left.\mathrm{cm} / \mathrm{s}^{1 / 2}\right)$ の場合

$$
\left\{\begin{array}{lr}
y=-0.057 x+1.855 & (0 \leqq x<15) \\
y=3.963 e^{-0.092 x} & (x \geqq 15)
\end{array}\right.
$$

○速度のPSI值が $180\left(\mathrm{~cm} / \mathrm{s}^{1 / 2}\right)$ の場合

$$
\left\{\begin{array}{lr}
y=-0.029 x+1.434 & (0 \leqq x<15) \\
y=4.084 e^{-0.094 x} & (x \geqq 15)
\end{array}\right.
$$


ここに, $y$ は補正係数， $x$ は等価 $\mathrm{N}$ 值である.ただ し，適用範囲は， $(0 \leqq x \leqq 25)$ であり，等価 $\mathrm{N}$ 值は細 粒分補正を実施しない值である. なお，速度の PSI 值 が 45〜180(cm/s $\mathrm{s}^{1 / 2}$ )の場合は，式(9)〜(11)を用いて内挿 補間し，速度の PSI 值が 45(cm/s $\left.{ }^{1 / 2}\right)$ 末満の場合は式(9), 90(cm/s $\left.{ }^{1 / 2}\right)$ 以上の場合は式(11)の值を用いる.

$<$ PSI に関する補正係数 $b_{7}>$

$$
y=\frac{1}{90} x
$$

ここに，yは補正係数，xは速度のPSI值 $\left(\mathrm{cm} / \mathrm{s}^{1 / 2}\right)$ である.

\section{(2) 防波堤重量 $\left(b_{8}\right)$}

図- 5〜図- 7に防波堤重量の変化による堤防モデルの 標準タイプに対する補正係数を示寸。ここで，標準タイ プは，表-1の caseA の堤防モデルである．なお，図-5〜 図-7に示している caseA 以外の補正係数は，法勾配，天 端幅，マウンド高等の影響を除外し，防波堤重量の影響 のみを確認することを目的として，ケース毎の沈下量を 標準タイプの沈下量で除した後，形状に関する補正係数 をさらに除して求めている. この結果，速度の PSI 值が 小さいケースは，防波堤重量が大きくなると急激に補正 係数が大きくなることが分かる，一方，速度の PSI 值が 大きいケースは，防波堤重量が大きくなるにしたがって， 徐々に補正係数が大きくなる傾向にある. このように, 速度の PSI 值の違いにより傾向が異なるため, 補正係数 は式(13)，及び式(14)により定義する，なお，速度の PSI 值 45 90 cm/s/2 の間は，それぞれの補正係数から線形補 間するものとする.

<速度の PSI 值が $45 \mathrm{~cm} / \mathrm{s}^{12}$ 未満>

$\begin{cases}y=1 & (0 \leqq x \leqq 40 \\ y=\frac{1}{600} x+\frac{14}{15} & (40<x \leqq 160) \\ y=\frac{1}{50} x-2 & (160<x)\end{cases}$

<速度の PSI 值が $90 \mathrm{~cm} / \mathrm{s}^{1 / 2}$ 以上 $>$

$\left\{\begin{array}{lr}y=1 & (0 \leqq x<40) \\ y=\frac{1}{120} x+\frac{2}{3} & (40 \leqq x)\end{array}\right.$

ここに, $y$ は補正係数, $x$ は単位面積当りの防波堤重 量 $\left(\mathrm{kN} / \mathrm{m}^{2}\right)$ とする.

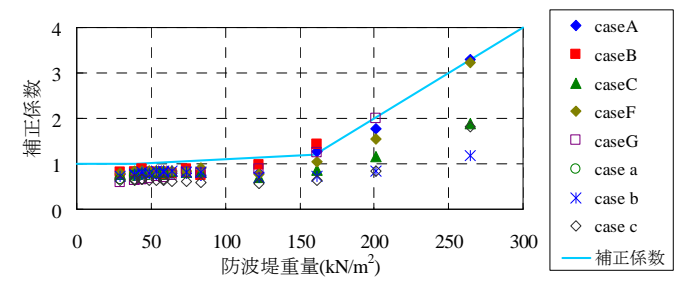

図-5 防波堤重量の違いによる補正係数(PSI $\left.=45 \mathrm{~cm} / \mathrm{s}^{12}\right)$

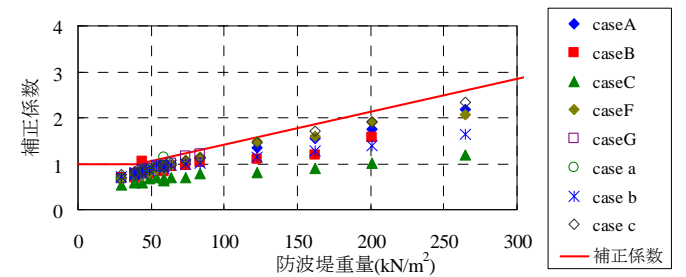

図-6 防波堤重量の違いによる補正係数 $\left(\mathrm{PSI}=90 \mathrm{~cm} / \mathrm{s}^{12}\right)$

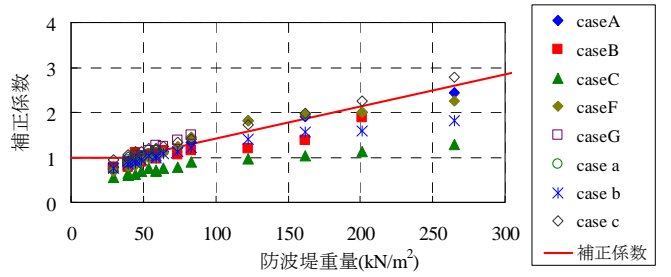

図-7＼cjkstart防波堤重量の違いによる補正係数 $\left(\mathrm{PSI}=180 \mathrm{~cm} / \mathrm{s}^{12}\right)$

\section{（3）堤体と捨石の違い $\left(b_{9}\right)$}

これまでの検討は，防波堤直下のマウンドの物性值を 堤体(等価 $\mathrm{N}$ 值 10)として検討を行ってきた. しかし，実 際は防波堤直下のマウンドは捨石材を使用するためこの 違いを適切に評価する必要がある，そこで，マウンド形 状が異なるケースを対象に，マウンドの物性值を捨石材 に変更して，等価 $\mathrm{N}$ 值 10 の場合との比較を行うことに より補正係数を算出した。 なお，捨石材の物性值は表3に示す通りとし，等価 $\mathrm{N}$ 值 10 の物性值も並記する.

図- 8に，捨石と堤体の違いによる沈下量比(捨石材/堤 体)を示す。この結果, 沈下量比は, 沈下量の大小にか かわらず，概ね一定の值となっている，また，沈下量比 の平均值を確認すると 1.08 となっており，マウンドを 堤体とした場合に比べ，捨石とした場合の方が，沈下量 が大きくなる傾向にあることが分かった。

図-9にマウンドを堤体とした場合と捨石とした場合 の, せん断ひずみ $\gamma_{\mathrm{m}}$ の最大值分布の一例を示す.この結 果，捨石材とすることにより，原地盤のせん断ひずみが 大きくなる傾向にある. 特に, 法尻付近では捨石のケー ス方が大きくなっている. これは，マウンドを捨石材と することにより，原地盤とのインピーダンス比が大きく なり，地震動の透過よりも反射の影響が大きく原地盤で のひずみが大きくなったためと考えられる．以上より， 堤体と捨石材の違いによる補正係数は 1.08 と寸る.

表-3 捨石物性值

\begin{tabular}{|c|c|c|c|c|c|c|c|c|}
\hline & $\begin{array}{c}\text { 単位体 } \\
\text { 積重量 } \\
\gamma\left(\mathrm{kN} / \mathrm{m}^{3}\right) \\
\end{array}$ & $\begin{array}{c}\text { 基淮有效拘 } \\
\text { 束圧 } \\
\sigma_{\mathrm{ma}}\left(\mathrm{kN} / \mathrm{m}^{2}\right)\end{array}$ & $\begin{array}{c}\text { 基淮初期世 } \\
\text { 儿断剛性 } \\
\mathrm{G}_{\mathrm{ma}}\left(\mathrm{kN} / \mathrm{m}^{2}\right)\end{array}$ & $\begin{array}{c}\text { 基準初期 } \\
\text { 体積剛性 } \\
\mathrm{K}_{\mathrm{ma}}\left(\mathrm{kN} / \mathrm{m}^{2}\right)\end{array}$ & $\begin{array}{c}\text { 内部摩 } \\
\text { 擦角 } \\
\phi_{\text {(Deg.) }}\end{array}$ & $\begin{array}{l}\text { ポアソ } \\
\text { ン比 } \\
v\end{array}$ & $\begin{array}{c}\text { 間隙 } \\
\text { 率 } \\
\mathrm{n} \\
\mathrm{n}\end{array}$ & $\begin{array}{l}\text { 最大減 } \\
\text { 衰定数 } \\
\mathrm{h}_{\max } \\
\end{array}$ \\
\hline 捨石 & 20 & 98 & 180,000 & 469,400 & 40 & 0.33 & 0.45 & 0.24 \\
\hline 等価 $\mathrm{N}$ 值 10 & 20 & 98 & 108,000 & 282,000 & 41 & 0.33 & 0.45 & 0.24 \\
\hline
\end{tabular}

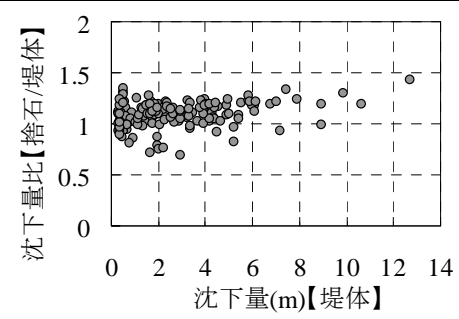

図-8 沈下量比(捨石/堤体) 


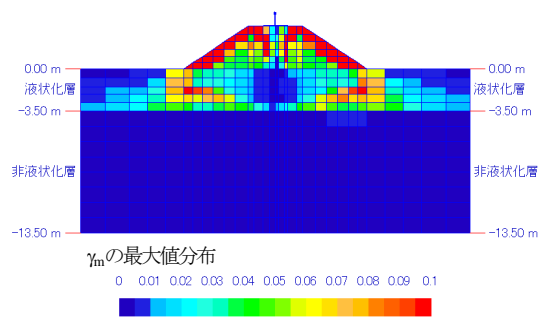

(1) 堤体

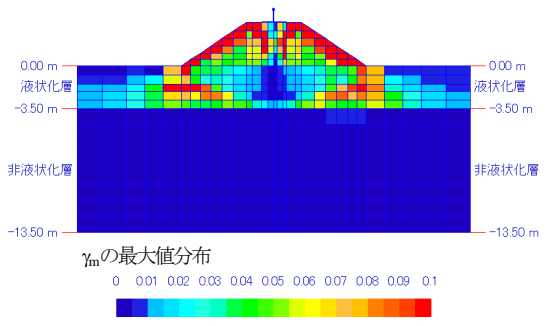

(2) 捨石

図-9 $\gamma_{\mathrm{m}}$ の最大值分布(caseA_H/W=1.0_ $\gamma=40 \_P S I=45 \mathrm{~cm} / \mathrm{s}^{1 / 2}$ )

\section{（4）防波堤のチャート式耐震診断システムの設定}

上記検討により，防波堤のチャート式耐震診断システ ムは式(15)により設定する。

$$
S=b_{1} b_{2} b_{3} b_{4} b_{5} b_{6} b_{7} b_{8} b_{9} S_{r}
$$

ここに，bは補正係数を表し，それぞれの適用範囲を 表- 4に示す。また， $S_{\mathrm{r}}$ は基準沈下量(1.5m)，Sは推定する 沈下量(m)である.

表-4 補正係数と適用範囲

\begin{tabular}{|c|l|c|}
\hline 記号 & \multicolumn{1}{|c|}{ 名称 } & 適用範囲 \\
\hline$b_{1}$ & マウンド天端幅 ${ }^{* 1)}$ & $2.0 \sim 8.0 \mathrm{~m}$ \\
\hline$b_{2}$ & マウンド高 & $1.5 \sim 7.0 \mathrm{~m}$ \\
\hline$b_{3}$ & のり勾配 & $1: 1.25 \sim 1: 3.0$ \\
\hline$b_{4}$ & 基礎地盤厚 & $0.0 \sim 20.0 \mathrm{~m}$ \\
\hline$b_{5}$ & 水深 $^{22}$ & - \\
\hline$b_{6}$ & 基礎地盤の等価N值 $^{* 3)}$ & $5 \sim 25$ \\
\hline$b_{7}$ & 速度のPSI值 & $0.0 \sim 457 \mathrm{~cm} / \mathrm{s}^{1 / 2}$ \\
\hline$b_{8}$ & 防波堤重量 $^{b_{9}}$ & $0.0 \sim 264.6 \mathrm{kN} / \mathrm{m}^{2}$ \\
\hline$b_{9}$ & 堤体と捨石材の違い(1.08) & - \\
\hline
\end{tabular}

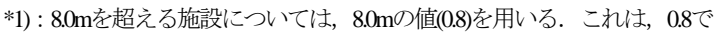
収斂していると判断できるためである(図-4参照).

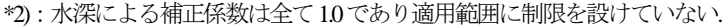
*3) : 細粒分含有率による補正を行わない值

\section{5. 動水圧の影響検討}

補正係数の検討では動水圧による影響を考えていない そこで，ここでは動水圧による影響の確認を行った。 caseA，caseJ，及び casef の H/W=1.0 のケースを対象に， 水位が壁体天端と同じであると仮定して, Westergaard に よる近似式を用いて算定した動水圧と等価な力が作用す るように付加質量を考慮して動的解析を実施した. 具体 的には、式(16)により付加質量を与え，式(17)により算出 される動水圧の作用位置に質点を設けることにより評価 した，比較結果を図- 10に示す.この結果，付加質量の
有無にかかわらず，防波堤天端の沈下量はほぼ同じであ ることが確認された．従って，防波堤の沈下量には動水 圧の影響は殆ど無いと判断した.

$$
\begin{aligned}
& m_{d}=\frac{7}{12} \frac{\gamma_{w}}{g} b H^{2} \cdot 2 \\
& y=\frac{3}{5} H
\end{aligned}
$$

ここに, $m_{\mathrm{d}}$ は付加質量 $(\mathrm{t}), \gamma_{\mathrm{w}}$ は海水の単位体積重量 $\left(\mathrm{kN} / \mathrm{m}^{3}\right), g$ は重力加速度 $\left(\mathrm{m} / \mathrm{s}^{2}\right), b$ は地震時動水圧の作用 方向に直角方向の躯体幅 $(\mathrm{m})(=1.0), H$ は水深(m), $y$ は動 水圧の作用位置(水面からの距離)(m)である.

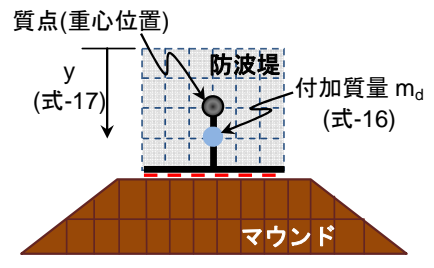

図-10 付加質量の設定イメージと付加質量有無の比較

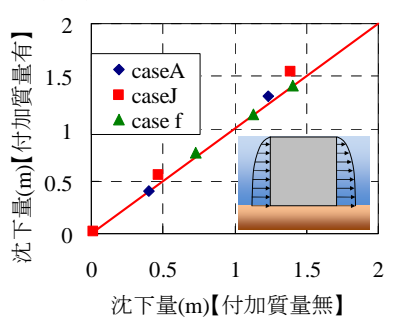

\section{6. 事例を用いた精度検証}

提案した防波堤のチャート式耐震診断手法を用いて， 既往事例に対する沈下予測を行い，本手法の精度検証を 行った．検討を行った既往事例は，兵庫県南部地震にお ける神戸第7防波堤1)，鳥取県西部地震における境港外港 中野地区東防波堤），港湾空港技術研究所で実施した1G 場模型実験9)の3つである. 神戸第7防波堤のみ詳述し他 の事例は，比較表のみ記載する.

神戸第 7 防波堤では，概ね $3 \mathrm{~m}$ 程度の沈下があつたと の報告がある. チャート式耐震診断手法に必要となる情 報は，図- 11より設定する. なお，置換砂の等価 $\mathrm{N}$ 值は, 文献 7 を参考に等価 $\mathrm{N}$ 值を 6.4 とした.

最終的に採用した諸元採用值と補正係数，及び予測沈 下量を表- 5に示す。この結果，予測沈下量 $\{$ 過剩間隙水 圧の消散による沈下量(以下，排水沈下量と称す．)を除 く\}が 5.08m と過大な評価となった. これは，チャート 式耐震診断手法では，沈下が進むにつれて増加する浮力 を考慮できないが，実現象では浮力の影響を受けており 特に沈下が大きい本ケースでは，この差が顕著に現れた ためと考えられる. これを解消寸るため, 現状の設置水 深での防波堤重量を用いてチャート式耐震診断手法で算 定した沈下量(1)(想定される最大)と, 沈下量(1)分の防波 堤が沈下したことによる浮力を考慮した条件でチャート 式耐震診断手法で算定した沈下量(2)(想定される最小)の 平均的な值に排水沈下量を加えた值をチャート式耐震診 断手法で算定する予測沈下量とした. 前述の 3 事例の沈 下量予測結果を表- 6に示す。若干過大評価ではあるが, 
概ね沈下量を評価できていることが確認できた．参考に, 算出された浮力を考慮した防波堤重量により沈下量を予 測し，前ステップとの防波堤重量の差がほぼゼロとなる まで繰り返し計算を実施すると, 神戸港第 7防波堤で予 測沈下量 4.08m(排水沈下量考慮)となり, 平均值を用い る場合に比へ，若干小さめの評価をすることが分かった。

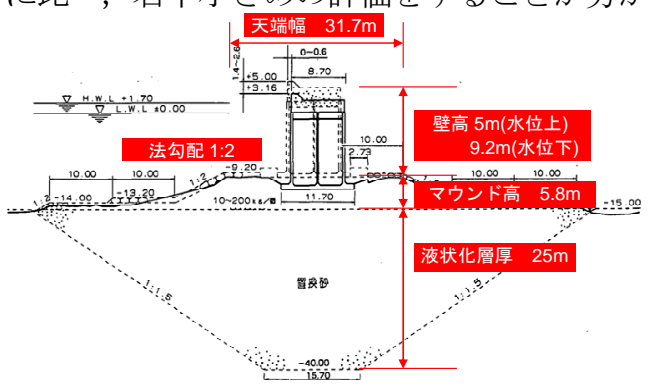

図-11断面図とチャートに必要な条件設定

表- 5 補正係数と予測鉛直変位

\begin{tabular}{|c|c|c|c|}
\hline 諸元項目 & 採用値 & 補正保数 & 摘要 \\
\hline \begin{tabular}{c|} 
等価 $\mathrm{N}$ 值 \\
\end{tabular} & 6.4 & 1.52 & \\
\hline 法勾配 & $1: 2$ & 0.85 & \\
\hline マウンド高 & $5.8 \mathrm{~m}$ & 1.5 & \\
\hline 被状化層厚 & $20 \mathrm{~m}$ & 1.11 & チャート式の上限值を採用 \\
\hline 天端幅 & $8 \mathrm{~m}$ & 0.8 & チャート式の上限値を採用 \\
\hline PSI值 & $85.07 \mathrm{~cm} / \mathrm{s}^{1 / 2}$ & 0.94 & $\begin{array}{l}\text { PI 波 } \\
\end{array}$ \\
\hline 防波堤重量 & $197 \mathrm{kN} / \mathrm{m}^{2}$ & 1.94 & $5 \times 21+9.2 \times 10$ \\
\hline 唅石 & - & 1.08 & \\
\hline 予测沈下量 & 5.08 & $<.8$ & \\
\hline
\end{tabular}

表-6 実被害, 実験結果と予測沈下量との比較

\begin{tabular}{|c|c|c|c|c|c|c|}
\hline & \multicolumn{6}{|c|}{ 沈下量(m) } \\
\hline & \multirow{2}{*}{$\begin{array}{l}\text { 実被害 } \\
\text {,奏験 }\end{array}$} & \multicolumn{5}{|c|}{ チャート式耐震診断手法 } \\
\hline & & 沈下量(1) & 沈下量(2) & \begin{tabular}{|l|} 
平均値 (1), (2)) \\
\end{tabular} & 排水沈下量 & 予測沈下量 \\
\hline $\mid \begin{array}{l}\text { 神戸港 } \\
\text { 第7防波堤1) }\end{array}$ & 3.00 & 5.08 & 3.08 & 4.08 & 0.75 & 4.83 \\
\hline $\begin{array}{l}\text { 境港外港 } \\
\text { 中野地区東防波堤 }\end{array}$ & 0.50 & 0.83 & 0.82 & 0.83 & 0.09 & 0.92 \\
\hline 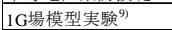 & 4.32 & 5.06 & 3.77 & 4.42 & 0.54 & 4.96 \\
\hline
\end{tabular}

\section{7. まとめ}

堤防タイプの沿岸構造物のチャート式而震診診断シス テムに，防波堤重量に関する補正係数，及び堤体の物性 に関する補正係数を加えることにより，重力式防波堤の チャート式而震診断手法を提案した. 被災断面や実験結 果との比較により, 本研究で提案したチャート式而震診 断手法では, 若干過大に評価するものの, 概社沈下量を 評価でることが確認された. 本研究では，堤防タイプを 拡張したものであるため, 精度向上に資寸るためには,
防波堤を想定した2次元解析を実施することも考えられ る. しかしながら, 被災断面との比較を確認する限り, 本モデルでも概ね沈下量を予測できるものと考える．ま た，防波堤自体に偏心がある構造(スリット式)，あるい は消波ブロック被覆式に対しては残留水平変位が発生す ると予想される. これらの施設に対する検討, 及び本研 究で比較した3事例以外の事例についても比較検討し精 度向上に資することが今後の課題である.

\section{参考文献}

1) 井合進, 一井康二, 森田年一: 兵庫県南部地震にお ける防波堤の有効応力解析, 第 24 回地震工学研究発 表会講演論文集, pp.477-480, 1997.

2）東島義郎，藤田郁夫，一井康二，井合進，菅野高弘， 北村道夫 : 沿岸構造物のチャート式耐震診断システ ムの開発, 海洋開発論文集, 第 22 巻, pp.511-516, 2006.

3) 野津厚, 井合進 : 岸壁の即時被害推定に用いる地震 動指標に関する一考察, 第 28 回関東支部技術研究発 表会講演概要集, 土木学会関東支部, pp.18-19, 2001.

4) Iai,S., Matsunaga,Y. and Kameoka,T.: Strain Space Plasticity Model for Cyclic Mobility, Report of The Port and Harbor Research Institute, Vol.29, No.4, pp.27-56, 1990.

5) 森田年一, 井合進, H. Liu, 一井康二, 佐藤幸博 : 液状化 による構造物被害予測プログラム FLIP において必要な各 種パラメタの簡易設定法，港湾技研資料 No.869, 1997.

6) 沿岸構造物のチャート式耐震診断システム Ver1.00 利用マ ニュアル,2007.

7) 一井康二, 井合進, 森田年一: 兵庫県南部地震における ケーソン式岸壁の挙動の有効応力解析, 港湾技術研究所報 告 Vol.36, No.2, 1997.

8）井合進, 菅野高弘, 山㠃浩之, 長尾毅, 野津厚, 一井康 二，森川嘉之，小濱英司，西守男雄，佐藤陽子，田中剛， 海老原健介, 大村武史, 大槙正紀 : 平成 12 年(2000 年)鳥 取県西部地震による港湾施設等の被害報告, 港湾技術研究 所資料 No.1015, 2001.

9）大矢陽介，竹信正寛，菅野高弘，小濱英司：防波堤基礎 地盤の地震時変形特性に関する1g場模型振動実験と有効 応力解析, 港湾技術研究所資料No.1227, 2011.

\section{A FUNDAMENTAL STUDY ON THE SIMPLE EVALUATION METHOD OF THE SEISMIC PERFORMANCE OF BREAKWATER}

\section{Akito SONE, Naonori KUWABARA, Syuji YAMAMOTO, Masahiro MIZUTANI Takesi KONDOU, Toru MORIMOTO, Susumu IAI, Koji ICHII}

A breakwater is an important institution for protecting the property and the life of a back place from high tide or tsunami. In order to consider a design and disaster prevention planning, it is very important to evaluate appropriately the amount of subsidence in case of the earthquake of a breakwater. There is the finite element method as the technique of evaluating the amount of subsidence with sufficient accuracy.However, calculation load is large and it is unreal to verify many sections. So, this study examined the simple seismic capacity evaluation technique which changes to it. With this simple seismic capacity evaluation technique, three disaster examples etc. have been expressed. 